\title{
About The Repetitions In The Novel Of "Cholikushi"
}

Muazzama Foziliya

Student Faculty Of Turkic Studies, Tashkent State University Of Oriental Studies, Uzbekistan

Journal Website:

https://theamericanjou

rnals.com/index.php/ta

jssei

Copyright: Original content from this work may be used under the terms of the creative commons attributes 4.0 licence.

\section{ABSTRACT}

In this article, dialogue is based on the rapid circulation of the replication of the interlocutors, the replies is short, but mutually known to be treated. The term replication is "add again", the completion of a speech of one of the dialogue, the place where the replica is semical and grammatical is linked to each other. Replicta-repetitions are considered a lexical phonetical media, which is characterized by formative circulation in dialogial speech, in which re-consortation speech is repeating words, replication and repeated. The realization of the surprise is interpreted. The Turkish writer said the balls and compound-shaped replica-repetitions, which were found in dialogue in Rashod Nuri Guntekins, and they were explained according to the content of the expression. Replicta-repeats used in this play Surprise (köpeklere), flatter (Feride), rationale (ne zannedecekler), dangling (mutlaka geri alacağım), rude (doktorun kızı), query (Candarma), excitement (sevdim) representation of modal content is analyzed through examples. In the conclusion, the replications of replication and repetition depends on the tone of punctuation also depends on the tone of punctuation closed.

\section{KEYWORDS}

Language science, replication, dialogue, replacively, subjective modification, reproduction, the antibody content, punctuation.

\section{INTRODUCTION}

From the science of language, the dialogue is based on the fast exchanged of the interlocutors. The replications are distinguished by being short but mutually known. The word "replicate" is actually derived from Latin word "replication" and 
means "again" and mean "add". The term linguist is a speech, representing the word of replication and interlocutor, representing the word of the interlocutor" [21.669]. A. P.Yakubovkny said "The place is completed by one's speech of the dialogue". The replications of the dialogical speech semantic and grammatical towards each other. Replica and repetition a dialogical unity element that has always attracted the attention of linguists. While most researchers are content to describe some of the characteristics of replication, others are limited to describing the lexical means of repetition.

\section{THE MAIN FINDINGS AND RESULTS}

In addition, they interpret the concept of repetition differently. Some see it as a grammatical phenomenon, others as a lexical phenomenon. In the work of Russian linguists V. G. Vinokur, M. L. Mikhlina, V. Volkov, M. P. Svyatogor, N.Y. Shvedova and others, who studied dialogic speech, we find valuable insights into the peculiarities, differences, types of replications. In Uzbek linguistics, B. Urinbaev's views on repetition have a special value. He describes repetition as follows: "The next replica is made up of a replica (or repetition) based on the repetition of a word, part, or whole sentence in the previous replica [22.108]. Linguist $U$. Lafasov in his dissertation studied replication as a means of expressing the main subjective modality in dialogic speech [23.45]. Replica-repetition is a tool of lexicalphonetic method and represents a subjective modality in dialogic speech. B.Urinbaev says that in the replica-repetition the part of the speaker's speech can be repeated exactly or with a change of grammatical form. It is a common lexical-grammatical-phonetic phenomenon in repetitive dialogues. So, repetition is a syntactic structure inherent in speech, which is a dialogical unit. It repeats words from different word families. As you know, each word has its own lexical meaning. In addition, words and phrases are overloaded by the speaker - this is a subjective modality. Additional content in replicas, which are counted among the means of expressing subjective modality in dialogic speech (Note: The concept of modal content is broader than modal meaning because words are mostly used in dialogues) by tone. Replication is widely used in dialogues. They represent different modal meanings and subjective modality is important as a means of expression. In the dialogues of the novel "Cholikushi" by the Turkish writer Rashod Nuri Guntekin, we collected replicas in the form of words and phrases and tried to interpret them according to the content of the expression:

\section{Surprise content:}

- Köpeklere yiyecek vermek fena mı Ma Sör? dedim

- Hangi köpeklere? Ne yemeği?

- Viranedeki köpeklere... Ah, Ma Sör, beni görünce ne kadar sevindiklerini bilseniz... (P. 24).

\section{Translation:}

- Is it bad to feed dogs, masor?

- What kind of dogs? What kind of food?

- To the dogs in the ruins ... Oh, ma soeur (sister), I wish you could see how happy they were when I went...

\section{Compliments:}

- Çalıkuşu...

- Bu, nasıl isim böyle?

- Pardon, beni mektepte böyle çağırırlar da... Asıl ismim Feride. Kendim gibi yuvarlak, zarafetsiz bir isim.

- Feride Hanım... Sizin adınız da kendiniz gibi güzel, emin olun... 
Keşke oğluma sizin gibisini bulsam...(P. 35)

\section{Translation:}

- Cholikushi.

- Yeah, what a name that was?

- Sorry (sorry), that's what I'm called at school ... My real name is Farida. A rude name like myself.

- Ms. Farida ... Your horse is as beautiful as you are, rest assured.

\section{Highlights:}

- Biliyor musun Feride, dedi. Bu pozda yürüdüğümüzü gören arkadaşlar ne zannedecekler?

- Ne zannedecekler?

- Feride de âşık olmuş... Mişel'e derdini anlatıyor, diyecekler...(P. 45)

\section{Translation:}

- Do you know, Farida, what our friends would think if they saw us walking in this situation? She asked.

- What do they think?

- Farida is in love too ... She thinks she's telling Michelle about her pain.

\section{Threatening content:}

- Sözünü mutlaka geri alacaksın...

- Mutlaka geri alacağım, dedi. Ne istersen yapacağım, bırak beni...

- Ama öyle hatır için değil, beni aldatmak için değil...

- Peki, hatır için değil... Seni aldatmak için değil... Sahiden... (P. 64)

\section{Translation:}

- Take back your word...

- Well, I got it back. I'll do whatever you say, but let me go.

- But not for the sake of appearances, not to deceive me ... Really...

- Too much, not for the faint of heart, not to deceive you ... Really...

\section{The content of resentment:}

- Avrupa'ya bir seyahat varmış öyle mi? O, cevap verdi:

- Bir fikir. Daha doğrusu, benim fikrim de değil. Madrid'deki amcamın bir tasavvuru. Nereden duydun? Kısa bir tereddütten sonra:

- Doktorun kızından, dedim.

- Doktorun kızı, sana ne çok haberler veriyor, Feride? (P.94)

Translation:

- You travel to Europe, right??

- There is such an idea. To be honest, it's not mine, it's my uncle's dream in Madrid, he replied. "Where did you hear that"?

After a bit of hesitation:

- From the doctor's daughter, I said.

- The doctor's daughter is giving you so many messages, Farida?

6. Questionnaire content:

- Senin yengen yok mu?

- Var amma, o cara cız, onu da çoban Hasan'a veririz.

- Senin ağan ne iş görür?

- Candarma.

- Candarma ne yapar? Vehbi, düşüne düşüne başını kaşıdı; sonra:

- Canavarları çeser, dedi (182-bet)

Translation:

- What, don't you have a bride yet?

- Yes, but she is a black girl. We give it to Hasan shepherd.

- What does your brother do?

- Gendarmerie.

- What does the gendarmerie do? Wahbi thought. Then he scratched his head:

- He will slaughter the disbelievers.

\section{Exciting content:}


- Şimdi söyle bana bakayım Kâmran, gülbeşekeri beğendin mi?

Genç adam, gülerek cevap verdi:

- Beğendim.

- Sevdin mi?

- Sevdim.

- Bir daha söyle.

- Beğendim ve sevdim (P. 385).

\section{Translation:}

- Now tell me, Comron, did you like the rose? The young man laughed and replied:

- I liked it.

- Did you like it?

- I liked it.

- Say it again.

- I liked it.

\section{CONCLUSION}

Examples show that repetitions convey different meanings in dialogues. In these dialogues, replicas-repetitions such as surpriseemphasis, flattery-emphasis, emphasisinterest, threat-threat, resentment-emphasis, questioning emphasis, excitement-emphasis modal contents are expressed. In conclusion, replication is a unique unit that reflects the subjective attitude of the person to the situation and the psyche in the process of speech. They are followed by punctuation, depending on the tone.

\section{REFERENCES}

1. S.l. Ozhogov. Dictionary of the Russian language. M., 1968, p.669.

2. A.P. Yakubovsiy. About dialogical speech. In the collection "Russian speech", I. Petersburg, 1923, p.139.

3. B. Urinboev. Uzbek conversation. Tashkent: Science, 1982, P. 17.

4. U.Lafasov. Candidate's dissertation
"Expression of subjective modality in dialogic speech”.Tashkent, 1996, P. 45.

5. A.Hazratqulov. Candidate's dissertation "Dialogue speech in modern Uzbek literary language”. Samarkand:,1966;

6. A.Boboeva. Candidate's dissertation "Incomplete sentences in modern Uzbek literary language" Tashkent,1968;

7. I.Shodmonov. Candidate's dissertation "Words in modern Uzbek literary language". Tashkent:,1970;

8. S.M.Xoldorova. "Semantic and structural features of dialogic speech in modern Uzbek literary language" dissertation. Tashkent:,1974;

9. B. O'rinboev. "Problems of Uzbek speech syntax" doctoral dissertation. Samarkand:,1975;

10. M.Tursunpolatov. Candidate's dissertation “Uzbek speech". Tashkent:, 1982.

11. B. Urinboev. Vocabulary category in modern Uzbek. Tashkent:, Science,1972.

12. R. Amirov. Features of the syntax of Kazakh raucous speech. Almaty:,1972.

13. A.Nurmaxanova. "Types of speech according to modality and tone in Turkish languages" Ph.D. disser. Tashkent: 1966.

14. T.V. Borisova Lexical ways of expressing modality in modern German. Abstract of Cand. philol. sciences. Moscow:,1951.

15. V.F. Shabalin. On the question of expressing the category of modality in the Russian language. Abstract of can. Philosophy L.,1955.

16. D.I.Ganich. Modal functions of introductory words in modern Russian. Abstract of Cand. philol. sciences. Kiev: 1956.

17. A.B Shapiro. Modalize and predicate as signs and sentences in modern Russian. In the journal "Scientific reports to higher school". Philological Science Series. Moscow: 1958.

18. A.Nurmonov, N.Mahmudov, A.Ahmedov, 
S.Solikhojaeva. Semantic syntax of the Uzbek language. Tashkent:, Science,1992.

19. N.A. Agadazada. On the question of the category of mood and modality in the modern Azerbaijani language. Baku:, 1965.

20. G.N.Zikrillaev. Candidate's dissertation "System of modality and precision forms". Tashkent, 1978.

21. S.l. Ozhogov. Dictionary of the Russian language. Moscow:, 1968, P.669.

22. B. Urinboev. The work whose name is mentioned. Tashkent:, 1982, 108.

23. U.Lafasov. Candidate's dissertation "Expression of subjective modality in dialogic speech". Tashkent:, 1996, P. 45.

24. Lafasov, U. P. (2020). Relationship Between Turks And Japanese. International Journal of Scientific and Technology Research, 9(2), 3935-3938.

25. Lafasov, U. (2021). The Migration of the Japanese from the Center of Turan to the East. Journal of Contemporary Issues in Business and Government, 27(1), 380-388.

26. Rakhmonova, D. N. (2019). DEVELOPMENT OF MUSIC CULTURE FOR ELEMENTARY SCHOOL PUPILS WITH USING INTERACTIVE SOFTWARE. Theoretical \& Applied Science, (12), 101-106.

27. SAIDAZIMOVA, U. T. (2021). The issue of two women in the korean art world. Journal of Contemporary Issues in Business and Government, 27(3), 303-308. 